\title{
Hubungan Shalat Fardu Berjamaah Dengan Kecerdasan Emosional Pada Jamaah Mesjid Al Jihad Banjarmasin ${ }^{1}$
}

\author{
Ahmad Jauhari, Asmaran A.S, dan Siti Faridah ${ }^{2}$ \\ Jurusan Psikologi Islam Fakultas Ushuluddin dan Humaniora \\ Universitas Islam Negeri Antasari Banjarmasin
}

\begin{abstract}
Al Jihad Mosque Banjarmasin is a mosque that is identical with Muhammadiyah, this mosque is followed by many pilgrims and loyal at the time of the implementation of prayers fardu congregation. Jamaah consists of various groups regardless of background, both in terms of age, economy, organization and even the sick pilgrims (post-stroke) are actively involved in congregation. Active Jamaat prayers in congregation do not only come from residents around the mosque complex, but also many pilgrims who come from outside the mosque complex, even the distance difference between their residence with the mosque a few kilometers. In heavy rainy weather conditions, they still enthusiastically follow the prayers in congregation fardu mosque. In addition, there are things that are felt by pilgrims such as comfort, tranquility of heart and mind, emotional stability, silaturrahim which all is related to emotional intelligence.
\end{abstract}

In this study, the main problem is how is the relationship of prayer in congregation with emotional intelligence in the congregation of Al Jihad Mosque Banjarmasin?. The method used is quantitative and qualitative descriptive method with methodological arrangement such as approach and type of research, research location, population and sample, data and data source, procedure and data collection, quantitative and qualitative technical data analysis.

The result of the study found that there is a correlation between salat fardu congregation with emotional intelligence, this is proved by the data from questionnaires from 30 pilgrims (respondents) that is: able to control the impulse of worldly lusts with the highest opinion is $60 \%$ said yes and $40 \%$ stated sometimes. Motivating yourself with the highest opinion is $90 \%$ states yes and $10 \%$ states sometimes. Able to survive in the face of trials with the highest opinion is 86.67 states yes and 13, 33 states sometimes. No exaggeration with the highest opinion is $90 \%$ states yes and $10 \%$ states sometimes. Being able to set the mood with the highest opinion is $86.33 \%$ and 13.33 states sometimes. Keeping the stress burden does not cripple the thinking ability with the highest opinion is $90 \%$ states yes and $10 \%$ states sometimes. The ability to empathize and pray with the highest opinion is $90 \%$ say yes and $10 \%$ say sometimes.

Kata Kunci: Salat Fardu Berjamaah; Kecerdasan Emosional; Jamaah Mesjid Al Jihad Banjarmasin.

\footnotetext{
${ }^{1}$ Tulisan ini di dasarkan pada skripsi penulis pada Jurusan Psikologi Islam Fakultas Ushuluddin dan Humaniora UIN Antasari di bawah bimbingan penulis kedua dan ketiga.

${ }^{2}$ Korespondensi untuk tulisan ini ditujukan kepada penulis pertama email jauharibanjar81@gmail.com
} 


\section{Pendahuluan}

Mesjid merupakan rumah ibadah bagi umat Islam dengan tujuan utamanya adalah pelaksanaan salat fardu berjamaah disamping kegiatan sosial keagamaan lainnya. Namun sangat disayangkan banyak mesjid yang dibangun dengan susah payah, dana milyaran rupiah, dalam jangka waktu lama dan setelah berdiri kondisinya cukup memprihatikan seperti shaf-shaf salat berjamaah dalam pelaksanaan salat berjamaah tidak selalu penuh terisi dan jamaahnya loyal memakmurkan mesjid juga sangat sedikit.

Di Kota Banjarmasin terdapat sebuah mesjid yang mempunyai jamaah tetap dan banyak serta mempunyai loyalitas yang tinggi untuk komitmen selalu salat fardu berjamaah di mesjid. Mesjid tersebut adalah Mesjid Al Jihad Banjarmasin yang terletak di kawasan jalan Cempaka Banjarmasin. Mesjid ini merupakan mesjid yang berbasis organisasi keagamaan Muhammadiyah. Uniknya walaupun identik dengan Muhammadiyah namun mempunyai daya tarik tersendiri karena jamaah yang datang untuk salat fardu berjamaah bukan hanya dari kalangan Muhammadiyah saja tetapi dari berbagai macam latar belakang keagamaan. Berdasarkan informasi dari pengurus Mesjid Al Jihad Banjarmasin dan hasil observasi penulis di lapangan, jumlah jamaah yang melaksanakan salat fardu berjamaah di Mesjid Al Jihad Banjarmasin kurang lebih 300 orang setiap waktunya, dan mereka terdiri dari berbagai macam latar belakang baik dari segi usia, jenis kelamin, ekonomi, bahkan jamaah yang sudah renta serta sakit-sakitan pun mereka semua aktif membaur menjadi satu dalam salat berjamaah.

Saat ini perkembangan zaman menuntut seseorang bekerja dan berpikir keras sehingga otak kita diperas yang mana pada suatu titik maka lahirlah kejenuhan dan berakhir dengan stress. Bagi yang memiliki pondasi keimanan kuat maka pelarian dari stressnya adalah dengan beribadah untuk mendekatkan diri kepada Allah swt seperti salah satunya melalui salat fardu berjamaah di mesjid, dalam konteks ini merujuk pada konsep Psikoanalisanya Sigmund Freud disebut Displacement atau model pengalihan emosi ke dalam suatu aktivitas yang positif contohnya melaksanakan salat (zikir). ${ }^{3}$ Namun, bagi sebagian orang yang tidak mempunyai landasan iman yang kuat maka pelarian dari stresnya adalah dengan melakukan hal-hal negatif seperti minuman-minuman keras, ke

\footnotetext{
${ }^{3}$ M Darwis, “Emosi Penjelajahan Religio-Psikologis Tentang Emosi Manusia didalam Al Qur'an,” Jakarta: PT: Gelora Aksara Pratama, 2006. 264.
} 
tempat hiburan malam, mengkonsumsi narkoba bahkan bunuh diri yang tujuan akhirnya sebenarnya juga menginginkan ketenangan. Perlu suatu pencerahan bagi yang tidak mempunyai keimanan yang kuat yaitu adanya suatu intervensi batin melalui kegiatan peribadatan salat fardu berjamaah. Banyak yang tidak menyadari bahwa salat fardu berjamaah merupakan suatu terapi bagi jiwa-jiwa yang gelisah karena dihadapkan oleh tekanan kehidupan, dimana sebenarnya di dalam salat fardu berjamaah itu ada berbagai hikmah yang dapat mengeluarkan seseorang dari berbagai permasalahan serta kedamaian hidup.

Salat fardu berjamaah merupakan syi'ar Islam yang sangat agung, ia merupakan sebab terjalinnya saling mencintai sesama muslim, saling mengenal, saling mengasihi, saling menyayangi, menampakkan kekuatan, dan kesatuan karena kata Rasulluh SAW salat fardu berjamaah itu lebih utama dibandingkan salat sendirian dan pahalanya pun lebih besar 27 derajat dibandingkan dengan salat sendirian. Di antara keistimewaan ajaran Islam terdapat disyariatkannya bentuk ibadah dengan cara berjamaah, sehingga bisa menjadi representasi sebuah muktamar, ${ }^{4}$ Islam dimana umat Islam berkumpul bersama pada satu tempat dan satu waktu. Mereka bisa saling bertemu, bertatap muka, saling mengenal dan saling berinteraksi satu sama lain. Bahkan mereka bisa saling belajar atas apa yang telah mereka pahami.

Berdasarkan penelitian awal penulis dari hasil observasi di lapangan, kepada sebagian besar (responden) jamaah Mesjid Al Jihad Banjarmasin dan berdasarkan pengalaman penulis sebagai jamaah serta aktivis pemuda mesjid Al Jihad kurang lebih 14 tahun. Diketahui bahwa sebagian besar jamaah merasakan kenikmatan hidup dan ketenangan hati melalui salat fardu berjamaah. Para jamaah Mesjid Al Jihad Banjarmasin menyatakan ketenangan jiwa bukan dinilai dari segi materi atau ekonomi, namun mereka menilai bahwa ketenangan jiwa hanya bisa didapatkan melalui tempaan perjalanan spiritual yang mereka lalui dalam pelaksanaan salat fardu berjamaah. Contohnya para jamaah selalu rutin melaksanakan salat fardu berjamaah dalam kondisi apapun seperti dalam keadaan banyak masalah misalnya terlilit utang, tersandung masalah hukum, tertimpa masalah keluarga atau dalam keadaan sakit (ada sebagian jamaah yang kurang sempurna fisiknya disebabkan

\footnotetext{
${ }^{4}$ Menurut kamus umum Bahasa Indonesia yang dimaksud Muktamar ialah pertemuan, rapat musyawarah, konprensi. Lihat Poerwadarminta, Kamus Umum Bahasa Indonesia (Jakarta: Balai Pustaka, 1976), cet. ke-5. 659 .
} 
oleh dampak penyakit stroke sehingga pelaksanaan salat menggunakan kursi), di sisi lain ditemukan juga jamaah yang secara ekonomi baik dan memiliki jabatan tinggi di pemerintahan maupun di perusahaan swasta tetapi mereka tetap menyempatkan diri di sela kesibukan untuk melaksanakan salat fardu berjamaah di Mesjid Al Jihad Banjarmasin. Sisi lain dari keistimewaan Mesjid Al Jihad Banjarmasin terdapat beberapa jamaah mesjid yang domisilinya mencapai berkilo-kilo meter namun kegigihannya untuk mengikuti salat berjamaah di Mesjid Al Jihad Banjarmasin sangat luar biasa. Sesuatu yang menakjubkan juga terlihat dari perilaku positif karyawan Mesjid Al Jihad Banjarmasin sebagian dari mereka menyatakan bahwa penghasilan mereka sebagai karyawan mesjid masih kalah besar walaupun tawaran pekerjaan yang lebih bagus dalam artian penghasilan lebih tinggi pernah mereka dapatkan tetapi mereka tetap bertahan dengan alasan bekerja di lingkungan Mesjid Al Jihad Banjarmasin mereka menemukan ketenangan jiwa maupun bathin.

Fenomena yang terjadi di Mesjid Al Jihad Banjarmasin mengindikasikan suatu keadaan dimana jamaah nya mengalami pengalaman yang mengarahkan jiwa mereka untuk menjalani hidup secara tenang dan mampu mengendalikan emosi mereka secara benar yang bisa dikatakan mengindikasikan sebuah bagian dari kecerdasan emosional. Efek dari kecerdasan emosional membawa dampak kepada penempaan spiritual jamaah. Sebagian jamaah yang dulunya bersifat pemarah kini secara perlahan dapat mengendalikan amarahnya, mereka yang dulunya emosional atau mudah tersinggung dan sukar menerima kenyataan kini mereka terlihat ikhlas menerima kenyataan. Hal ini berkesesuaian dengan teori ESQ dalam perspektif Tasawuf Al-Ghazali karangan $\mathrm{H}$ Mubin bahwa ciri-ciri kecerdasan emosional adalah sebagai berikut : mampu mengendalikan dorongan nafsu (qana'ah, zuhud, wara), mampu memotivasi diri sendiri (niat bersungguh-sungguh, ikhlas), mampu bertahan dalam menghadapi cobaan (sabar istiqamah), tidak melebih-lebihkan kesenangan (syukur, tawadhu'), mampu mengatur suasana hati (tenang, gembira, pemaaf, malu, jujur), menjaga agar beban stress tidak melumpuhkan kemampuan berpikir (ridha), berempati (kasih sayang, suka menolong sesama, dermawan) dan berdoa (meminta pertolongan kepada Allah) ${ }^{5}$. Kecerdasan emosional ini terbentuk salah satunya melalui rajin melaksanakan kegiatan salat fardu berjamaah.

\footnotetext{
${ }^{5}$ H. Mubin, ESQ Dalam Perspektif Tasawuf Al-Ghazali (Banjarmasin: Antasari press, 2005). 83.
} 
Berdasarkan uraian di atas penulis tertarik untuk mengetahui lebih lanjut bagaimana hubungan salat berjamaah dengan kecerdasan emosional selanjutnya disusun dalam sebuah laporan yang diberi judul " Hubungan salat fardu berjamaah dengan kecerdasan emosional pada jamaah Mesjid Al Jihad Banjarmasin". Adapun yang menjadi tujuan penelitian ini adalah untuk mengetahui bagaimana praktek salat berjamaah yang dilakukan para jamaah mesjid Al Jihad Banjarmasin dan mendapatkan gambaran bagaimana pengalaman salat berjamaah yang dilakukan jamah Mesjid Al Jihad Banjarmasin mempunyai hubungan dengan kecerdasan emosional.

\section{Metode}

Pendekatan dan jenis penelitian

Jenis penelitian ini adalah penelitian lapangan dengan pendekatan deskriptif kuantitatif dan kualitatif yang bersifat eksploratoris karena berusaha mengeksplorasi kegiatan jamaah Mesjid Al Jihad Banjarmasin yang berkaitan dengan hubungan salat fardu berjamaah dengan kecerdasan emosional. Peneliti dalam hal ini juga merupakan jamaah dan aktivis Mesjid Al Jihad Banjarmasin yang mencoba meneliti antara hubungan salat fardu berjamaah dengan kecerdasan emosional.

\section{Subjek Penelitian}

Populasi dalam penelitian ini adalah semua jamaah Mesjid Al Jihad Banjarmasin yang berjumlah sekitar 300 orang setiap salat fardu lima waktu. Di penelitian ini penulis mengambil sampel $10 \%$ dari populasi sehingga besar sampel penelitiannya sebanyak 30 jamaah dari jumlah populasi. Teknik penarikan sampelnya menggunakan metode purposive sampling atau sampel bertujuan. ${ }^{6}$

\section{Metode Pengumpulan Data}

Teknik yang digunakan oleh peneliti dalam mengumpulkan data adalah :

1. Observasi di Masjid Al Jihad Banjarmasin untuk memperoleh data dan informasi yang diperlukan. Di sini penulis mengamati berbagai kegiatan salat fardu berjamaah di Mesjid Al Jihad, kemudian dampak perilaku dari salat fardu berjamaah tersebut.

\footnotetext{
${ }^{6}$ Suharsimi Arikunto, “Metode penelitian,” Jakarta: Rineka Cipta, 2002. 139.
} 
2. Wawancara yaitu pengumpulan data melalui wawancara secara mendalam dan tanya jawab secara langsung kepada responden penelitian yang dapat memberikan keterangan kepada peneliti tentang pandangan, kesan dan pengalaman mereka selama aktif mengikuti salat fardu berjamaah mesjid Al Jihad.

3. Dokumentasi yaitu mengumpulkan buku-buku, arsip-arsip dan catatan yang ada hubungannya dengan penelitian dari studi pustaka, arsip pada Mesjid Al Jihad Banjarmasin.

4. Kuesioner, melakukan penyebaran kuesioner kepada sampel (jamaah Mesjid Al Jihad Banjarmasin) untuk mengetahui tanggapan mereka mengenai hubungan salat fardu berjamaah dengan kecerdasan emosional.

Beberapa jenis teknik yang digunakan oleh peneliti di atas diperuntukkan agar bisa saling melengkapi sehingga tujuan penelitian dapat tercapai sesuai apa yang diharapkan penulis.

\section{Data dan sumber data}

Data yang diperlukan dalam penelitian ini meliputi: data primer yaitu data yang di dapat dari hasil observasi, angket dan wawancara mendalam kepada jamaah Mesjid Al Jihad Banjarmasin khususnya jamaah yang dijadikan sampel serta beberapa pengurus Mesjid Al Jihad Banjarmasin sebagai sumber informasi. Data yang dicari adalah mengenai kegiatan peribadatan salat fardu berjamaah yang dilakukan oleh jamaah (sampel) penelitian yang berkaitan antara hubungan salat fardu berjamaah dengan kecerdasan emosional. Sedangkan data sekunder dalam penelitian ini adalah data yang diperoleh dari buku-buku, majalah, arsip atau catatan-catatan mesjid yang berhubungan dengan kegiatan peribadatan di Mesjid Al Jihad Banjarmasin.

\section{Teknik Analisis Data}

Analisis data yang digunakan adalah analisis deskriptif kuantitatif dan kualitatif. Analisis data deskriptif yang digunakan untuk data yang diperoleh berupa kumpulan hasil kuesioner kemudian diperhitungkan mempergunakan teori distribusi frekuensi. Sedangkan analisis kualitatif digunakan untuk memperkuat hasil data yang diperoleh dari angket yang 
telah diperhitungkan dengan angka-angka atau berupa kode-kode dimana angka atau kodekode tersebut penulis jelaskan melalui uraian deskriptif. Kedua analisis data tersebut kemudian dihubungkan dengan teori-teori yang disampaikan oleh para ahli atau para pakar Psikologi Barat maupun Psikologi Islam, sehingga diperoleh gambaran yang tepat mengenai hubungan salat fardu berjamaah dengan kecerdasan emosional para Jamaah Mesjid Al Jihad Banjarmasin.

\section{H a s i 1}

Berdasarkan hasil perhitungan kuisioner di atas maka penulis membuat suatu rekapitulasi penelitian untuk memudahkan menganalisis hubungan salat fardu berjamaah dengan kecerdasan emosional.

Tabel 1

Rekapitulasi Hasil Kuesioner Kecerdasan Emosional Jamaah Mesjid Al Jihad Banjarmasin

\begin{tabular}{|c|c|c|c|c|}
\hline No & Pernyataan & Ya & $\begin{array}{l}\text { Kadang- } \\
\text { kadang }\end{array}$ & Tidak \\
\hline 1 & $\begin{array}{l}\text { Mengendalikan dorongan nafsu } \\
\text { duniawi }\end{array}$ & $\begin{array}{c}18 \\
60 \%\end{array}$ & $\begin{array}{c}12 \\
40 \%\end{array}$ & $\begin{array}{l}0 \\
0\end{array}$ \\
\hline 2 & Mampu memotivasi diri sendiri & $\begin{array}{c}27 \\
90 \%\end{array}$ & $\begin{array}{c}3 \\
10 \%\end{array}$ & $\begin{array}{l}0 \\
0\end{array}$ \\
\hline 3 & $\begin{array}{l}\text { Mampu bertahan dalam menghadapi } \\
\text { cobaan hidup }\end{array}$ & $\begin{array}{c}26 \\
86,67 \%\end{array}$ & $\begin{array}{c}4 \\
13,33 \%\end{array}$ & $\begin{array}{l}0 \\
0\end{array}$ \\
\hline 4 & Tidak melebih-lebihkan kesenangan & $\begin{array}{c}27 \\
90 \%\end{array}$ & $\begin{array}{c}3 \\
10 \%\end{array}$ & $\begin{array}{l}0 \\
0\end{array}$ \\
\hline 5 & Mampu mengatur suasana hati & $\begin{array}{c}26 \\
86,67 \%\end{array}$ & $\begin{array}{c}4 \\
13,33 \%\end{array}$ & $\begin{array}{l}0 \\
0\end{array}$ \\
\hline 6 & $\begin{array}{l}\text { Mampu menjaga agar beban stress } \\
\text { tidak melumpuhkan kemampuan } \\
\text { berpikir anda }\end{array}$ & $\begin{array}{c}27 \\
90 \%\end{array}$ & $\begin{array}{c}3 \\
10 \%\end{array}$ & $\begin{array}{l}0 \\
0\end{array}$ \\
\hline 7 & Berempati dan berdoa & $\begin{array}{c}27 \\
90 \%\end{array}$ & $\begin{array}{c}3 \\
10 \%\end{array}$ & $\begin{array}{l}0 \\
0\end{array}$ \\
\hline
\end{tabular}




\section{Diskusi}

Dari tabel di atas dapat diambil satu analisis mengenai hubungan salat fardu berjamaah dengan kecerdasan emosional pada jamaah Mesjid Al Jihad Banjarmasin dengan indikatorindikator pembahasan sebagai berikut:

\section{Mampu mengendalikan dorongan nafsu dunia}

Berdasarkan keterangan pada tabel 1, pertanyaan kepada responden mengenai "mampu mengendalikan dorongan nafsu duniawi" terlihat jumlah pendapat tetinggi yang mengatakan "ya" adalah sebanyak 60 \% atau 18 suara dari 30 jamaah.

Berdasarkan jawaban responden ini membuktikan bahwa seseorang yang sering melaksanakan ibadah salat fardu berjamaah dengan baik dan benar akan berpengaruh terhadap perubahan mental perilakunya menjadi lebih baik, dimana semua itu akan tercermin di dalam perilaku kehidupan sehari-harinya yang mampu mengendalikan dorongan nafsu duniawi (qana'ah, zuhud, wara). Ia akan berhati-hati dalam bersikap dan berbuat (bertindak ) karena ia merasa setiap perbuatannya akan dilihat Allah atau dengan kata lain setiap perbuatan itu akan diminta pertanggung jawabkannya pada hari akhir nanti.

Observasi penulis di lapangan juga melihat diantara jamaah mesjid terdiri beberapa kelompok strata sosial yaitu terdiri dari mulai berprofesi pelajar dan mahasiswa, ibu-ibu rumah tangga, tukang ojek, buruh, tukang becak, PNS, karyawan swasta, dokter, manager dan direktur, pejabat pemerintah maupun kepolisian seperti perwira polisi, kepala dinas, mantan Bupati, dan lain sebagainya. Sebut saja untuk jamaah yang berprofesi tukang becak dan Kepala Dinas di salah satu instansi pemerintah di Kota Banjarmasin yang sempat penulis wawancarai, ${ }^{7}$ untuk berprofesi tukang becak walaupun dari segi ekonomi penghasilan rendah akan tetapi beliau masih rutin menyempatkan salat fardu berjamaah dalam rangka melaksanakan syiar atau perintah syariat agama. Walaupun secara kategori ekonomi termasuk orang yang tergolong miskin, tetapi ia tetap dapat mengendalikan dirinya bersikap hati-hati dalam berbuat atau bertindak agar jangan sampai melakukan perbuatan yang dilarang oleh agama seperti mencuri, menipu dan lain-lain. Inilah dampak positif dari salah satu melaksanakan syariat agama seperti salat fardu, sesuai dengan Firman Allah dalam surah Al-An kabuut ayat 45:"salat fardu mencegah dari perbuatan keji mungkar".

\footnotetext{
${ }^{7}$ AR (nama samaran atau inisial), wawancara pribadi, Mesjid Al Jihad, 22 Januari 2014
} 
Komitmennya yang kuat dalam melaksanakan takwa kepada TuhanNya membuat hidupnya merasa lebih tenang dan barakah ia terkadang mendapat rizki yang tak disangkasangka. Karena ia beliau aktif salat fardu berjamaah dimesjid membuat jamaah lain iba dan memberikan hadiah berupa beras, duit dan lain-lain. Dan juga terkadang di becanya terdapat beberapa amplop yang berisi duit. Mungkin inilah kata Tuhan dalam surah at Thallaq yang artinya bahwa "Tuhan akan memberikan rizki yang tak disangka-sangka apabila ia bertakwa".

Salah satu kasus jamaah lain yang berhasil penulis wawacara dengan inisial GR, ${ }^{8}$ walaupun beliau sekarang menjadi pejabat disalah satu kepala dinas instansi pemerintahan yang ada di kota Banjarmasin. Namun, beliau tetap aktif salat fardu berjamaah sampai sekarang. Sebenarnya salat fardu berjamaah sudah beliau lakukan sejak dari masih bujangan sampai menikah dimana saat itu masih posisi jabatan biasa (beliau sudah \pm 14 tahun berjamaah di Mesjd Al Jihad). Dan hal itu sudah mendarah daging atau menjadi suatu ikatan di dalam diri atau jiwa, sehingga apabila sudah masuk azan tanda dari salat fardu itu sudah tiba beliau pun bergegas untuk memenuhi panggilan azan tersebut agar bisa melaksanakan salat fardu berjamaah di mesjid. Jadi, setiap ada acara atau pelatihan dinas kantor beliau berusaha bisa sebelum waktu salat fardu tiba atau bila belum selesai beliau sendiri akan berusaha keluar dulu sebentar untuk salat fardu berjamaah di mesjid, karena kata beliau ketika kita mendengar azan dan kita tdak memenuhi salat fardu berjamaah di mesjid maka di dalam hati ini timbul perasaan gelisah, hati tidak tenang karena merasa ada yang kurang terhadap apa yang dilakukan. Menariknya walaupun jarak mesjid Al-Jihad dengan kantornya lumayan jauh berkilo-kilo meter yakni alamat kantornya berada di jalan kayu tangi sedangkan mesjid al-Jihad berada di jalan Cempaka besar (selisih jarak sekitar $\pm 4 \mathrm{~km}$ ) beliau tetap berusaha untuk menyempatkan diri agar dapat salat fardu berjamaah di mesjid Al-Jihad. Alasan beliau setelah melakukan perjalanan di beberapa mesjid di Banjarmasin beliau merasa cocok di Mesjid Al Jihad Banjarmasin ini, manfaat yang beliau rasakan efeknya dari salat fardu berjamaah selain memenuhi syariat agama yaitu dengan salat fardu berjamaah beliau merasa ketenangan hati dan stress pun hilang setelah menunaikan salat fardu berjamaah.

\footnotetext{
${ }^{8}$ GR ((nama samaran atau inisial), wawancara pribadi, Mesjid Al Jihad, 24 Januari 2014.
} 
Ketenangan hati dan pikiran tersebut diakui beliau mempunyai korelasi khususnya dalam ruang lingkup pekerjaan contoh kecilnya sikap dalam memimpin anak buah di kantor terasa lebih bijak dan arif dalam bersikap. Selain itu, pergaulan di jamaah Mesjid Al Jihad Banjarmasin ini terasa ikatan emosionalnya seperti keluarga sehingga timbul saling sikap bantu membantu, sharing informasi di dalam kehidupan sehari-hari. Melihat semua pengalaman ini membenarkan pendapat dokter Alexis Carol yang menyatakan bahwa seseorang yang rutin melaksanakan salat fardu dan salat fardu sunnah akan berdampak atau tumbuhnya sebuah kecerdasan ${ }^{9}$ baik berupa kecerdasan emosional dan kecerdasan spritual. Hal ini sesuai juga dengan apa yang di kemukakan oleh Mubin tentang konsep kecerdasan emosional berdasarkan pandangan dari Imam Ghazali, di mana salah satu cirinya seseorang yang cerdas secara emosional itu "memiliki kemampuan mengendalikan dorongan nafsu ( qana'ah, zuhud, wara).

Kedua kasus di atas terdapat hubungan antara seseorang yang sering melaksanakan salat fardu berjamaah dengan kecerdasan emosionalnya. Kalau kita analisis dalam dimensi sufi dalam konsep ESQ Imam Ghazali dalam maqam qana'ah, zuhud, wara terbentuklah suatu analisis penulis yaitu:

1. Untuk beliau yang berprofesi tukang beca tersebut bisa dikatakan masuk dalam maqam qana'ah dan wara. Mengapa? Karena walaupun beliau hidup dalam keadaan miskin tetapi beliau tetap istiqomah untuk bertakwa mendekatkan diri dengan Tuhan. Beliau ikhlas menerima keadaannya, secara tidak langsung kondisi ini juga menunjukkan ridha terhadap takdir. Kemudian dalam maqam wara; dimana dalam beberapa kali dalam suatu tempat yang berbeda beliau sempat ditawari atau diberi kesempatan untuk naik haji gratis dari pembiayaan seseorang yang kaya dermawan, namun, kesempatan tersebut beliau tolak karena dengan alasan tidak siap dan beliau merasa saat ini masih belum mampu karena masih berprofesi sebagai tukang beca yang notabanenya secara materi finansial tidak mampu. Melihat kondisi ini beliau meurungkan niat dermawan tersebut untuk membiayai naik hajinya gratis dengan maksud menghindari fitnah di masyarakat. Tetapi bukan berarti beliau tidak mau naik haji, tapi suatu hari apabila beliau telah siap dan mampu maka ia akan memenuhi tawaran haji tersebut.

\footnotetext{
${ }^{9}$ Muhammad Bahnasi, Salat fardu sebagai terapi psikologi (Bandung: Mizania, 2007). 62.
} 
2. Beliau jamaah yang berprofesi saat ini menjabat sebagai Kepala Dinas di salah satu instansi pemerintah ini bisa juga di katakan dalam maqam zuhud. Mengapa? Karena walaupun saat ini sudah memiliki jabatan tinggi sebagai pejabat pemerintah (kepala dinas) bukan menghalanginya untuk tetap istiqomah untuk bertakwa kepada Allah mendekatkan diri dengan Tuhannya khususnya tetap mengamalkan salat fardu berjamaah di mesjid di sela-sela kesibukannya menjalankan tugas sebagai kepala dinas instansi. Sehingga apabila tiba azan waktu salat fardu tiba beliau akan segera memenuhi panggilan tersebut. Karena beliau menganggap jabatan sebagai kepala dinas hanyalah urusan dunia (maksudnya tugas jabatan terhadap pekerjaan tetap dilakukan sebaik-baiknya secara profesional) tetapi apabila tiba waktu salat fardu beliau tetap melaksanakan perintah Tuhan untuk salat fardu berjamaah di mesjid.

Sementara untuk responden yang menjawab pertanyaan kadang-kadang "mampu mengendalikan dorongan nafsu duniawi" terlihat jumlah suara 12 orang atau $40 \%$ dari 30 jamaah Mesjid Al Jihad. Prosentase ini menunjukkan bahwa seseorang itu walaupun sudah merasa beriman dan menjalankan syariat agama tidak menutup kemungkinan tidak konsekuen atau tidak istiqomah dalam ketaatan. Namun, semua itu wajar dan hal itu juga yang membuktikan perkataan Rasulullah saw yang artinya "seseorang muslim paginya mengaku beriman tetapi sore harinya ia bisa tidak beriman". Perkataan Rasulullah lainnya menyebutkan "keimanan seseorang itu kadang bisa naik dan juga bisa turun, atau kata lain bisa berubah-ubah".

\section{Mampu memotivasi diri sendiri}

Berdasarkan keterangan tabel 1 di atas, pertanyaan kepada responden mengenai "mampu memotivasi diri sendiri (niat bersungguh-sungguh, ikhlas)" dengan pendapat tertinggi adalah $90 \%$ suara atau 27 orang dari 30 jamaah menyatakan ya. Ini menandakan bahwa ada hubungan antara salat fardu berjamaah dengan kecerdasan emosional khususnya yang berkaitan dengan mampu memotivasi diri sendiri.

Salat fardu berjamaah mampu membangkitkan motivasi diri para jamaah, apabila seorang jamaah telah terpikat dengan kegiatan salat fardu berjamaah maka dia akan selalu termotivasi untuk berdiri, bergerak dan berangkat menuju mesjid walau terkadang mencuri 
waktu ditengah kesibukan, walau badan terkadang dirasakan masih sakit dan seribu persoalan masih membebeni otak. Berdasarkan hasil observasi dari penulis ada salah seorang jamaah dengan inisial $\mathrm{BS}^{10}$ dia adalah seorang pekerja wiraswasta dibidang pengetikan komputer.

Menurut BS, terkadang ada pekerjaan yang menumpuk ketika waktu salat fardu zuhur masuk maka dia segera meninggalkan pekerjaannya dan menutup tempat usahanya walau risikonya banyak pelanggan kembali pulang karena tempat pengetikannya tutup. Namun, baginya dengan salat fardu berjamaah adalah suatu rangkaian motivasi yang berurutan dalam lima waktu yaitu ketika masuk waktu shubuh ini menandakan awal pekerjaan segera dimulai dari waktu salat fardu subuh inilah terpancar doa dan harapan semoga hari ini mendapatkan rezeki yang banyak, kemudian masuk waktu salat fardu zuhur disini kembali terucap rasa syukur atas waktu yang diberikan Allah SWT karena masih bisa bekerja mencari nafkah dan mensyukuri semua pendapatan yang dia terima kalaupun usaha sedang sepi disini ia segera tumpahkan semua persoalannya dalam sujud terakhir salat fardu zuhur, semoga dalam jam-jam berikutnya akan mengalir rezeki baginya, memasuki salat fardu ashar merupakan tempat untuk mengadu yang terbaik setelah satu hari penuh berjibaku dengan berbagai ragam persoalan hidup dan mengucap syukur atas semua rezeki yang diberikan pada hari ini. Terus tiba waktu salat fardu magrib dan Isya inilah saat melepaskan kepenatan dunia untuk segera bergabung dengan komunitas orang-orang saleh melalui salat fardu kegiatan salat fardu magrib setelah itu mendengar tausiyah, baca kitab suci Alquran sampai waktu salat fardu Isya masuk dan berharap besok pagi masih diberikan umur, kesehatan, dan motivasi untuk menafkahi anak istri.

Melihat fenomena di atas menjadikan salat fardu sebagai sebuah bentuk terapi Islam yang efektif dalam memberikan semangat, kesungguhan seseorang dalam mencapai sesuatu. Hal itu senada apa yang di ungkapkan Salim apabila seseorang telah selesai melaksanakan salat fardu mereka akan lebih giat dan penuh gairah pada dirinya. Selama salat fardu berlangsung akan memperbaharui tekad kemauan serta harapannya dan memberikan kekuatan luar biasa dalam menciptakan karya-karya besar. ${ }^{11}$ Maka sangat beruntung seseorang yang rajin mengamalkan salat fardu khususnya salat fardu berjamaah

${ }^{10}$ BS (nama inisial atau samaran) wawancara pribadi, Mesjid al Jihad, 27 Januari 2014

${ }^{11}$ Ahmad Husain Salim, "Menyembuhkan Penyakit Jiwa dan Fisik," Jakarta: Gema Insani, 2009. 283. 
berdampak terhadap nilai mereka akan menciptakan kreativitas-kreativitas atau inovasi baru dalam bekerja maupun menjalani tantangan hidup. Semua ini sesuai apa yang di ungkapkan Mubin mengenai konsep kecerdasan emosional Imam al Ghazali maupun Daniel Goleman bahwa seseorang yang cerdas secara emosional mampu memotivasi dirinya dalam menjalani kehidupan ini.

Sementara untuk responden yang menyatakan kadang-kadang sebesar $10 \%$ ini mengindikasikan bahwa secara alamiah, manusia, psikologis motivasi manusia itu bisa naik dan bisa turun seperti urusan pekerjaan dan kadang juga dalam beribadah namun hal ini hal yang manusiawi karena walau ada kemalasan tetap saja para jemaah Mesjid Al Jihad Banjarmasin dengan sebagai kekurangan selalu aktif melakukan kegiatan salat fardu berjamaah.

\section{Mampu bertahan dalam menghadapi cobaan}

Berdasarkan keterangan tabel 1, pertanyaan kepada responden mengenai "mampu bertahan dalam menghadapi cobaan (sabar, istiqomah)". Dengan pendapat tertinggi adalah Ya sebanyak $86,67 \%$. Ini menandakan bahwa ada hubungan antara salat fardu berjamaah dengan kecerdasan emosional yang indikatornya mampu bertahan dalam menghadapi cobaan.

Kondisi ini membuktikan bahwa seseorang yang sering mengamalkan salat fardu berjamaah akan memberikan stimulan atau vitamin agar mampu bertahan dalam menghadapi cobaan. Semua itu ada peran sabar dan sikap istiqomah seseorang dalam bertakwa, karena menurut ajaran Islam bahwa seseorang muslim sebelum mengaku beriman maka ia akan di uji Tuhan keimanannya, dan apabila lulus maka ia kan di naikkan derajatnya. Untuk itu seseorang hendaknya membekali diri agar mampu menghadapi setiap cobaan yang datang salah satunya dengan rajin melaksanakan salat fardu. Sesuai apa yang dianjurkan Tuhan dalam QS Al Baqarah :153 artinya "minta pertolonganlah dengan Allah yaitu dengan cara sabar dan salat fardu". Karena didalam salat fardu terkandung makna dan manfaat dalam mengatasi kegelisahan, kecemasan, ketenangan hati dalam menghadapi masalah. Banyak penelitian yang menyimpulkan salah satunya apa yang dikemukakan Arif Wibisono dalam bukunya bahwa keteraturan seseorang dalam menjalankan salat fardu memiliki korelasi terhadap tingkat kecemasan. Maksudnya makin teratur seseorang 
melaksanakan ibadah salat fardu, maka makin rendah tingkat kecemasan di dalam dirinya. ${ }^{12}$ Maksudnya juga seseorang yang mendapat musibah atau ujian sering diliputi dengan kecemasan, kegelisahan di hati, maka dengan rajin mendekatkan diri dengan Tuhan khususnya melalui pelaksanaan salat fardu akan terbantui dalam menghadapi semua bentuk musibah tersebut. Maka, tidaklah mengherankan apabila seseorang yang mengamalkan salat fardu berjamaah berdampak terhadap kecerdasan emosional, seperti apa yang dituturkan Daniel Goleman maupun al-Ghazali.

Namun, untuk responden yang menjawab "kadang-kadang" sekitar 4 orang atau 13,33 $\%$ dari jamaah menunjukkan masih ada terdapat beberapa orang yang rutin salat fardu berjaamaah tetapi mereka masih belum mampu bertahan dalam manghadapi cobaan. Keadaan sikap ini bisa saja jamaah tersebut masih perlu proses waktu untuk memahami hakikat salat fardu berjamaah, selain itu juga perlu dibekali dengan ilmu batin atau hakikat sebuah kehidupan (ilmu tasawuf) agar bisa ridha terhadap apa yang sudah di takdirkan Tuhan kepada dirinya dimana masalah cobaan hidup biasanya langsung bersentuhan dengan psikis atau jiwa manusia, dan salah satu solusinya adalah melalui ilmu tasawuf yang terdapat di dalam dimensinya berhubungan dengan masalah batin atau kejiwaan manusia.

\section{Tidak melebih-lebihkan kesenangan}

Berdasarkan keterangan tabel 1, pertanyaan kepada responden mengenai "perilaku yang tidak belebih-lebihkan kesenangan terhadap apa yang sudah di dapatkan selama ini (syukur, tawadhu) "dengan pendapat terbanyak adalah sebanyak $90 \%$ atau 27 orang menyatakan ya.

Jamaah atau responden yang sudah rutin mengamalkan salat fardu berjamaah seperti apa yang ditemui penulis bahwa mereka walaupun sudah mendapatkan kedudukan ekonomi yang lebih baik atau menjai pejabat/pimpinan dikantor tidak membuat mereka memamerkan atau berfoya-foya terhadap memilikinya, justru malah mereka bisa mengendalikan ego bersenang-senangnya atau kata lainnya mereka lebih tawadhu (rendah hati). Keadaan yang lebih baik tersebut mereka tetap istiqomah menjalankan perintah agama yakni tetap melakukan salat fardu berjamaah, sikap seperti inilah mungkin dapat

${ }^{12}$ Moh Sholeh, Bertobat Sambil Berobat (Hikmah, 2008). 265. 
dikatakan seseorang itu sebagai hamba yang tetap ingat melakukan syukur kepada TuhanNya. Kalau kita analisis dalam pendekatan psikologi inilah yang di namakan kecerdasan emosional menurut Daniel Goleman maupun Imam Ghazali ; bahwa salah satu ciri kecerdasan emosional yang dimiliki seseorang adalah perilakunya mampu tidak melebih-lebihkan terhadap apa yang sudah di dapatkan atau diperoleh saat ini. Kata lainnya menurut istilah Imam Ghazali orang tersebut mampu bersikap syukur dan tawadhu.

Sedangkan, untuk responden yang menjawab "kadang-kadang" sekitar 3 orang atau $10 \%$ dari total responden menunjukkan keadaan ini bagian dari sebuah proses waktu keimanan seseorang dalam memahami ajaran agamanya. Dimana suatu saat nanti apabila tetap istiqomah melaksanakan ajaran syariat dan menambah pemahaman agama Islam secara mendalam insya Allah akan bisa mengendalikan nafsu atau ego dirinya.

\section{Mampu mengatur suasana hati}

Berdasarkan keterangan tabel 1, pertanyaan kepada responden mengenai" responden yang sering salat fardu berjamaah mapmu mengatur suasana hati (jiwa menjadi tenang, gembira, pemaaf, malu, jujur)". Hasil prosentasi responden yang mengatakan "ya" sebanyak 26 orang atau 86,67 \%. Hal ini menunjukkan seseorang melaksanakan salat fardu berjamaah di mesjid itu mampu membuat tenang hati seseorang, tidak stres, lebih lembut hatinya (pemaaf), menghilangkan kegelisahan. Mengapa keadaan ini bisa terjadi dalam diri atau jiwa seseorang? Karena menurut kesaksian jamaah bahwa menyela waktu dari kesibukannya sehari-hari dengan mampir sebentar ke mesjid pada waktu salat fardu tiba untuk beribadah menghadap Tuhannya, ternyata dapat merilekkan pikirannya ya sebelumnya sumpek atau bahkan pekerjaan, tugas maupun problem yang sebelumnya tidak terpecahkan ternyata setelah selesai melaksakan salat fardu ditemukan jalan keluarnya dan juga pikiran yang kalut pun akhirnya dapat reda, kondisi ini berkesesuaian dengan firman Tuhan QS. Ar-Rad :112 yang artinya "hanya dengan mengingat Allah hati akanmenjadi tenang". Kondisi inilah yang disebut oleh para peneliti kejiwaan yang mengatakan salat fardu itu terdiri dari beberapa aspek, diantaranya aspek rileksasi karena melakukan gerakan seperti olah raga sehingga membuat badan sehat dan rileks, aspek meditasi karena dalam salat fardu mengandung aspek meditasi dimana adanya pemfokusan pikiran dalam satu titik 
pikiran yang dalam salat fardu kita disuruh khusyu dan thuma'ninah yang semua itu pada saat salat fardu kita hanya diperintahkan fokus menghadap Allah Swt.

Dengan fokusnya pikiran kita hanya memposisikan jiwa raga kita pada saat salat fardu menghadap Allah swt disitulah akan timbul gairah dan semangat baru, ketenangan karena diri kita merasa bersama Allah yaitu seseorang yang mempunyai kekuasaan dalam mengatur kehidupan manusia. Selain itu, di dalam salat fardu juga mengandung bacaan dan doa. Hal ini dalam kaca mata ilmu hipnosis merupakan bagian mensugesti diri sendiri atau self hypnosis. Orang yang khusyu dan thuma'ninah dalam salat fardu bisa juga kita katakan dalam kondisi flow, karena khusyu nya seseorang dalam salat fardu dan terlihat hanya fokus pada satu titik pikiran yakni hanya menghadap Allah saja pikirannya, sisi yang lain mereka merasakan nikmatnya merasakan kehadirannya bersama Tuhan saat salat fardu, kondisi inilah yang dinamakan dalam kondisi flow dalam istilah Psikologi Positif yang telah dikemukakan oleh tokohnya Mihaly Csikszentmihaly, ahli Psikologi dari University of Chicago, Amerika Serikat.

Sementara untuk responden yang menjawab "kadang-kadang" sebanyak 4 orang atau $13,33 \%$, angka tersebut menunjukkan masih terdapat jamaah yang masih belum merasakan atau menikmati secara penuh tentang efek dari mendekatkan diri dengan Tuhan khususnya dalam melaksanakan salat fardu berjamaah.

Kondisi itu bisa juga disebebakan salah satunya karena belum bisa selalu melakukan salat fardu dengan khusyu dan nyambung (shilah) dengan Tuhan atau bisa juga karena kemampuan pemahaman ilmu batin di dalam dirinya belum mantap dalam memahami ajaran islam. Tetapi kondisi ini menurut penulis masih wajar bila terdapat keadaan kadangkadang karena dalam melaksanakan ajaran agama Islam ini perlu proses, latihan, bertahap jika di dalam konteks metode sufi terdapat beberapa tingkatan atau maqam seseorang dalam proses pendekatan diri dengan TuhanNya.

\section{Menjaga agar beban stress tidak melumpuhkan kemampuan berpikir}

Berdasarkan keterangan tabel 1, pertanyaan kepada responden mengenai "salat fardu berjamaah mampu menjaga agar beban stress tidak melumpuhkan kemampuan berpikir (ridha)". Responden yang menjawab "ya" sebanyak 27 orang atau $90 \%$. 
Kondisi ini menunjukkan salat fardu berjamaah memang mampu membuat diri seseorang terhindar dari stress. Untuk itu tidak salah bila para Psikolog Muslim seperti Usman Najati merumuskan salat fardu merupakan bagian salah satu dari terapi mengatasi stress. Karena dengan salat fardu seseorang biasanya dapat merasakan ketenangan hati atau melahirkan kebahagiaan, ungkap Dzahabi. Sebenarnya kecerdasan emosional dengan salah satu cirinya "mampu menjaga agar beban stress tidak melumpuhkan kemampuan berpikir dapat kita setarakan dengan ridha alam konsep kecerdasan Imam al-Ghazali. Mengapa? Karena apabila seseorang sudah mampu bersikap ridha terhadap setiap ketentuan Tuhan yang menimpa dirinya. Maka, hidupnya di jamin akan mendapatkan ketenangan dan ketentraman hati tanpa di liputi rasa gelisah apalagi kegalauan hati.

Orang yang sudah terbiasa ridha terhadap ketentuan takdir Tuhan dalam sudut pandang ilmu kesehatan juga berdampak positif terhadap kesehatan tubuhnya karena apapun takdir Tuhan ia akan berusaha selalu senang, gembira,bahagia ikhlas menerimanya. Dan orang yang berbahagia serta selalu senang jauh dari kecemasan akan berdampak terhadap kesehatan tubuhnya. Dr. Shigeo Haruyama, ${ }^{13}$ seorang dokter bedah dan juga ahli ilmu pengobatan timur mengatakan jika seseorang mendapatkan tekanan atau problem yang tidak disenangi dan ia menyikapi dengan sikap positif maksudnya bisa menerima keadaan itu dengan ikhlas maka otak akan melepaskan zat-zat bagi tubuh dan hasilnya tubuhpun akan terhindar dari penyakit. Karena kata Haruyama keberhasilan manusia dalam mengatasi atau menghindarkan diri dari penyakit di dalam tubuh manusia itu hormon yang berperan adalah hormon kebahagiaan. Di sisi lain terdapat juga hormon yang disebut beta-endorfin yaitu hormon yang paling berkhasiat diantara hormon kebahagiaan. Menurutnya ada korelasi antara kedua jenis hormon ini. Jika seseorang mendapat penolakan, "Tidak, saya tidak mau", di dalam otaknya akan melepaskan hormon noradrenalin yang bersifat racun. Sebaliknya, jika dalam situasi yang sama dia mendapat jawaban "itu bagus", hormon beta-endorfin yang akan mengalir.

Sementara untuk responden yang menjawab "kadang-kadang" sebanyak 3 orang atau $10 \%$ dari total responden. Fakta di lapangan ini memang tidak bisa dihindarkan karena setiap orang berbeda-beda kemampuannya dalam menyikapi permasalahan hidup, namun dengan istiqomah melakukan salat fardu dan ditambah dengan belajar ajaran Islam secara

\footnotetext{
${ }^{13}$ Shigeo Haruyama, The miracle of endorphin (Mizan Qanita, 2015). 20-22.
} 
menyeluruh jamaah tersebut bisa saja menjadi lebih baik. Dari kesimpulan ini selain mengamalkan rutin salat fardu berjamaah hendaknya kita juga agar berusaha dapat menerima dengan ikhlas dan ridha dalam menghadapi setiap persoalan kehidupan karena terkadang apa yang kita inginkan di dalam hidup ini tak sesuai dengan harapan dan bagi kita orang beriman dan bertakwa agar menganggap semua itu sudah qadar Allah swt sehingga kita terbebas dari penyakit fisik dan batin.

\section{Berempati dan Berdoa}

Berdasarkan keterangan tabel 1, pertanyaan kepada responden mengenai "Berempati (kasih sayang, suka menolong sesama, suka berbagi/dermawan) dan berdoa (meminta pertolongan kepada Allah". Responden yang menjawab "ya" sebanyak 27 orang atau $90 \%$.

Kondisi ini menunjukkan bahwa dengan salat fardu berjamaah yang biasa bertemu atau berinteraksi dengan banyak orang akan menumbuhkan sikap di dalam diri rasa empati ,kepedulian kasih sayang, suka bantu membantu, cerdas secara sosial. Karena dengan selalu berjamaah seperti terasa keluarga sendiri tutur jamaah, ikatan emosional lumayan terbangun kuat. Silaturahmi yang dilakukan dengan berjamaah disana terasa lebih nyaman, akrab. Itu terbukti dari proses perjuangan jamaah dalam membangun Mesjid Al Jihad Banjarmasin tersebut. Sehingga seseorang yang salat fardu berjamaah di mesjid tersebuta akan terasa ruh jihadnya.

Tidak sedikit diantara jamaah di sana yang sebenarnya jarak rumahnya lumayan berkilo-kilo tetapi mereka tetap antusias agar bisa menuju kesana. Yang jelas kata Rasulullah SAW "mukmin itu dengan mukmin yang lainnya adalah saudara, dan hadist lainnya menyebutkan "mukmin itu seperti satu bangunan/tubuh, maka apabila satu mengalami sakit dan lainnya pun akan mengalami sakit".

Rasa empati yang mencakup suka menolong, dermawan, kasih sayang ini selaras apa yang dikemukan para ahli psikologi yang mengatakan salah satu aspek salat fardu itu adalah mengandung aspek kebersamaan karena dengan berjamaah di mesjid menghindarkan diri seseorang dari perasaan keterasingan yang merupakan dari penyebab munculnya penyakit kejiwaan. Sebab dengan rajin pergi ke mesjid untuk salat fardu berjamaah maka perasaan terasing dari orang lain itu akan hilang. 
Di mesjid kita banyak bertemu orang dari semua kalangan. Apalagi di Mesjid Al Jihad Banjarmasin jamaahnya heterogen, ${ }^{14}$ dari kalangan biasa sampai intelektual ataupun pejabat pemerintah maupun pimpinan perusahaan. Dari situ kita akan banyak kenalan dan banyak mendapatkan informasi-informasi baru, bahkan lowongan kerja pun akan kita peroleh lewat jaringan disana. Belum lagi bila jamaah aktif di setiap kegiatan mesjidnya sepeti mengaji, puasa sunnah bersama, mendengar ceramah, aktif pada kegiatan di kepanitiaan zakat fitrah, pelaksanaan qurban pada hari raya Idul Adha, terlibat pada saat pembangunan Mesjid Al Jihad. Semua jamaah yang aktif pada kegiatan yang disebutkan sebenarnya salah satu bagian dalam konteks psikologi sosial ia merasa mendapat kan penerimaan dilingkungan sosialnya karena bergabunga dalam kelompok yang positif, selain itu aktivitas itu bisa juga dikatakan sebuah bentuk aktualisasi diri kalau menurut istilah Viktor Frankl karena menurut Frankl walaupun orang itu sudah kaya ataupun pintar memiliki segala ia akan mengalami kehampaan dalam hidup atau kata lainnya hidupnya tidak bermakna apabila tidak terlibat dalam kehidupan sosial masyarakat. Aktif dalam kegiatan keagamaan di mesjid itu sebenarnya akan menumbuhkan sikap kecerdasan spiritual. Responden adalah jamaah Mesjid Al Jihad Banjarmasin yang biasa salat fardu di Mesjid Al Jihad Banjarmasin tentulah ia akan selalu berdoa kepada TuhanNya baik dalam salat fardu maupun sesudah salat fardu untuk menyampaikan keinginan dan pengharapannya kepada Tuhan. Dengan berdoa kepada Allah SWT mereka akan merasa terbantui permasalahannya. Semua uneg-uneg yang membuatnya bingung, gelisah dengan berdoa akan terlepaskan semua penyakit psikis tersebut. Kita bisa melihat seseorang yang rajin salat fardu dengan tidak atau dengan orang yang menjauhi agama keadaannya akan berbeda artinya kadang masalah sikapnya kurang tenang karena tidak ada tempat untuk mengadu atau membantu setiap persoalannya. Semua perkataan atau permintaan tersebut bisa juga bila di lihat dalam kaca mata teori hypnosis merupakan bagian dari "auto sugesti". Dan dalam doa juga terkandung aspek chatarsis dalam istilah konsep Psikoterapi Psikoanalisa Sigmund Freud. Karena ia mencurahkan semua permasalahannya langsung kepada Allah SWT. Sedangkan untuk respoonden yang menjawab "kadang-kadang" sebanyak 3 orang atau $10 \%$ dari total responden. Menurut penulis jika dilihat dari sudut

\footnotetext{
${ }^{14}$ Menurut kamus umum Bahasa Indonesia yang dimaksud dengan heterogen ialah serbaneka, berlainan macam; berbeda sifat; tidak sejenis; terdiri dari berbagai macam unsur. Lihat Poerwadarminta, Катиs Umит Bahasa Indonesia (Jakarta: Balai Pustaka, 1976). Cet ke 5. 354.
} 
pandang psikologi kepribadian memang dipengaruhi oleh faktor sifat dasar yang dimiliki seseorang sebelumnya. Namun, dengan rutin terapi salat fardu berjamaah kemudian ditambah lagi mengkaji pemahaman ilmu agama Islam lainnya khususnya masalah batin yang biasa kita temui di dalam tasawuf insya Allah semua itu dalam proses waktu secara bertahap akan hilang sedikit demi sedikit maksudnya sikap empatinya akan menjadi lebih baik lagi.

\section{Kesimpulan}

Adanya hubungan antara salat fardu salat fardu berjamaah dengan kecerdasan emosional hal ini dibuktikan dengan adanya data dari hasil kuisioner dari 30 jamaah (responden) yaitu :

1. Mampu mengendalikan dorongan nafsu duniawi dengan pendapat tertinggi adalah 60 $\%$ menyatakan ya dan $40 \%$ menyatakan kadang-kadang.

2. Memotivasi diri sendiri dengan pendapat tertinggi adalah $90 \%$ menyatakan ya dan 10 \% menyatakan kadang-kadang.

3. Mampu bertahan dalam menghadapi cobaan dengan pendapat tertinggi adalah 86,67 menyatakan ya dan 13, 33 menyatakan kadang-kadang.

4. Tidak melebih-lebihkan kesenangan dengan pendapat tertinggi adalah $90 \%$ menyatakan ya dan $10 \%$ menyatakan kadang-kadang.

5. Mampu mengatur suasana hati dengan pendapat tertinggi adalah $86,33 \%$ dan 13,33 menyatakan kadang-kadang.

6. Menjaga agar beban stress tidak melumpuhkan kemampuan berpikir dengan pendapat

7. Berempati dan berdoa dengan pendapat tertinggi adalah $90 \%$ menyatakan ya dan $10 \%$ menyatakan kadang-kadang.

Saran

Terdapat sejumlah saran dari penelitian yang dilakukan ini, yaitu diharapkan hasil ini dapat dijadikan sebagai bahan kajian Psikologi Islam khusyusnya dalam ranah psikoterapi Islam untuk mempelajari prilaku kejiwaan manusia dalam membentuk kualitas diri yang lebih sempurna dan mendapatkan kebahagiaan di dunia dan di akhirat. Diharapkan hasil 
ini dapat dijadikan sebagai salah satu studi ilmiah guna pengembangan ilmu pengetahuan umumnya di Fakultas Ushuluddin dan Humaniora khususnya di Jurusan Psikologi Islam.

\section{Kepustakaan}

Arikunto, Suharsimi. “Metode penelitian." Jakarta: Rineka Cipta, 2002.

Darwis, M. “Emosi Penjelajahan Religio-Psikologis Tentang Emosi Manusia didalam Al Qur'an." Jakarta: PT: Gelora Aksara Pratama, 2006.

H. Mubin. ESQ Dalam Perspektif Tasawuf Al-Ghazali. Banjarmasin: Antasari press, 2005.

Haruyama, Shigeo. The miracle of endorphin. Mizan Qanita, 2015.

Muhammad Bahnasi. Salat fardu sebagai terapi psikologi. Bandung: Mizania, 2007.

Poerwadarminta. Kamus Umum Bahasa Indonesia. Jakarta: Balai Pustaka, 1976.

Salim, Ahmad Husain. “Menyembuhkan Penyakit Jiwa dan Fisik.” Jakarta: Gema Insani, 2009. Sholeh, Moh. Bertobat Sambil Berobat. Hikmah, 2008. 